\title{
RESISTANCE OF BACTERIAL CULTURES TO NON-OXIDISING WATER TREATMENT BACTERICIDES BY ADAPTATION
}

\author{
V. S. Brözel, B. Pietersen and T. E. Cloete
}

\section{INTRODUCTION}

Surfaces in industrial water systems (e.g. cooling-water systems in power plants and mines) are prone to colonisation by bacteria. The resulting biofilms cause biofouling, leading to a decrease in system efficiency and life expectancy. The nature and mechanisms of biofouling have been reviewed extensively (Cloete et al., 1992; Ford and Mitchell, 1990). Many systems are treated with bactericides to eliminate or reduce biofouling. The various bacteria present differ in their susceptibility to the various bactericides available (Brözel and Cloete, 1991a). Some have a low degree of resistance under pure culture conditions, but play an important role in the microbial communities in cooling waters. Examples are Pseudomonas stutzeri and Bacillus cereus which often attain a dominant position in communities after bactericide treatment (Brözel and Cloete, 1992b). This indicates some form of adaptation to the bactericide over time (Jones et al., 1991b). These bacteria appear to adapt to grow in the presence of otherwise inhibitory concentrations of certain bactericides. We have previously established that bacteria isolated from cooling-water systems do develop an increased level of resistance to bactericides, and grow in the presence of otherwise inhibitory concentrations (Brözel and Cloete, 1991b). Resistance can be defined in two ways meaning either (a) the ability of an organism and its progeny to multiply or (b) to remain viable under conditions that would usually bring about the opposite (Gilbert and Wright, 1987). In this paper the first definition will hold as biofouling control aims at the prevention (ie. inhibition) of bacterial growth and metabolic activity in water systems. The phenomenon of bacterial resistance to bactericides can be due to one of three reasons. Certain bacteria, notably gram-negative, have a high degree of inherent resistance to many bactericides due to the barrier nature of their cell envelope (Gilbert and Wright, 1987). Secondly, certain resistance mechanisms are genetically encoded and can be acquired by the contraction of an R plasmid (Franklin and Snow, 1981). Thirdly bacteria have, in certain cases, been reported to adapt to a more resistant physiological state (Jones et al., 1989). Decreased susceptibility of bacteria in cooling-water systems to non-oxidising bactericides after periods of treatment has been ascribed to the selection for less sensitive species (Characklis, 1990). Organisms less susceptible to the bactericide survive treatment and become dominant in the system, rendering the community more resistant to the following treatment.

Many authors have reported that bacteria acquire resistance to antiseptics such as quaternary ammonium compounds (QACs) (Heinzel, 1989: Jones et al., 1989; Sakagami et al., 1989) and biguanides (Heinzel, 1989; Jones et al., 1989). Development of resistance to aldehyde-releasing bactericides (eg. hexahydro1,3,5-triethyl-s-triazine) is also documented (Eagon and Barnes, 1986). Biofilm bacteria have been reported to be up to one hundred times more resistant to chlorine dioxide than are free-floating ones (LeChevalier et al, 1988). Costerton and Lashen (1983) reported inherent resistance of biofilm bacteria to an isothiazolone-based bactericide due to the impermeability of the extracellular polysaccharide layer surrounding cells to the bactericide.

Water-cooling systems are often treated with isothiazolone, thiocarbamate or chlorinated phenol - based bactericides (Cloete et ai, 1992). Isothiazolones are non-oxidizing, do not release formaldehyde and are 
not membrane-active (Collier et al., 1990). They react oxidatively with thiols to form disulphides. Chlorinated phenols uncouple oxidative phosphorylation from respiration (Gilbert and Brown, 1978, Wallhaüßer, 1988). The antimicrobial mechanism of thiocarbamates has not been reported to date. The objective of this study was to investigate the rate at which pure cultures of bacteria, isolated from watercooling systems, increase their tolerance to four bactericides: dichlorophen, thiocarbamate, isothiazolone and the quaternary ammonium compound alkyl dimethyl ammonium chloride during growth in the presence of sub-inhibitory concentrations of these bactericides. For this purpose one Gram-positive and two Gram-negative isolates found to survive bactericide treatment in cooling-water systems were chosen for the investigation.

\section{MATERIALS AND METHODS}

\section{$\underline{\text { Cultures and media used }}$}

Isolates found to attain a dominant position in cooling-water communities after various bactericide treatment regimes (Pseudomonas stutzeri, $P$ aeruginosa and Bacillus cereus were used maintained on R2A agar slants containing 1\% glycerol, and subcultured monthly) (Brözel and Cloete, 1992a,b).

\section{$\underline{\text { Bactericides evaluated }}$}

Dichlorophen (2,2'-methylenebis(4-chlorophenol); Merck); thiocarbamate (sodium dimethyldithiocarbamate; Fluka); isothiazolone (a stabilised mixture of N-methyl isothiazolone and 5-chloro-Nmethyl isothiazolone; Thor Chemicals); quaternary ammonium compound (alkyl dimethyl ammonium chloride; Merck).

\section{Determination of the minimum inhibitory concentration (MIC)}

Bacterial strains were cultured in $100 \mathrm{ml} \mathrm{R} 2 \mathrm{~A}$ broth under orbital shaking at $100 \mathrm{opm}$ for $24 \mathrm{~h}$ at $30^{\circ} \mathrm{C}$. One $\mathrm{ml}$ of culture was withdrawn, centrifuged at $10000 \mathrm{xg}$ for $5 \mathrm{~min}$, resuspended in $1 \mathrm{ml}$ sterile deionised water, recentrifuged and resuspended in $1 \mathrm{ml}$ sterile water. In the case of 2,2'-methylenebis(4chlorophenol) and sodium dimethyldithiocarbamate, two loops full were inoculated into half-strength tryptic soy broth (TSB) (Biolab) containing various concentrations of the bactericides employed. In the case of isothiazolone and QAC, cell concentrations were determined spectrophotometrically at $540 \mathrm{~nm}$ and diluted to ca. $2 \times 107 \mathrm{cfu} / \mathrm{ml}$. Aliquots of $10 \mu \mathrm{l}$ were inoculated into the bactericide-containing broths. Tubes were incubated at $30^{\circ} \mathrm{C}$ for $24 \mathrm{~h}$. The lowest concentration of bactericide showing absence of growth, was taken to be the MIC.

\section{Induction of resistance}

One $\mathrm{ml}$ of the shake-culture was transferred to $100 \mathrm{ml}$ fresh $\mathrm{R} 2 \mathrm{~A}$ broth containing bactericide at one quarter of the concentration of the MIC as determined. After $24 \mathrm{~h}$ growth the new MIC was determined as above and a new shake-culture was inoculated. This procedure was repeated 8 times in the case of dichlorophen and isothiazolone, 11 times in the case of thiocarbamate and 34 times in the case of the QAC. In the case of isothiazolone, three parallel cultures of each isolate were exposed in order to determine whether the increase of resistance followed a fixed pattern, or whether it was a random process. Samples from broths were streaked out routinely onto R2A agar, and Gram stains were prepared to check for purity.

\section{RESULTS}

\section{2'-Methvlenebis(4-chlorophenol)}

All initial strains acquired a considerable degree of resistance over and above the initial value during growth in the presence of sub-inhibitory 2,2'-methylenebis(4-chlorophenol) (Figure la). B cereus 
increased its resistance over the 15 -day exposure period from $20-75 \mu \mathrm{g} \mathrm{ml}^{-1}$. The resistance of the $B$ cereus culture increased during the period of sub-inhibitory exposure. The rate of increase was, however, neither linear nor immediate. After 5d the resistance dropped slightly, and started increasing again after 9d. $P$ stutzeri increased its resistance from $22-80 \mu \mathrm{g} \mathrm{ml}^{-1}$. After $24 \mathrm{~h}$ of sub-inhibitory exposure, $P$ stutzeri became more susceptible, but after this its resistance increased. Again, the rate of increase was neither linear nor instantaneous. P aeruginosa adapted at a steady rate during the period of exposure from 38$78 \mu . \mathrm{g} \mathrm{ml}^{-1}$.

\section{$\underline{\text { Sodium dimethvldithiocarbamate }}$}

All three bacteria became increasingly resistant to the thiocarbamate during sub-inhibitory exposure (Figure $\mathrm{lb}$ ). B. cereus increased its resistance over the 15 -day exposure period from $6^{-1} 32 \mu \mathrm{g} \mathrm{ml} \mathrm{m}^{-1}$. The resistance of $B$. cereus decreased slightly during the first $3 \mathrm{~d}$ of sub-inhibitory exposure, then it increased almost linearly. P. stutzeri increased in resistance from $12-310 \mu \mathrm{g} \mathrm{ml}^{-1}$. After $24 \mathrm{~h}$ of subinhibitory exposure, it doubled in resistance then resistance increased slowly until $1 \mathrm{Id}$ of exposure, after which the rate of increase increased. After $19 \mathrm{~d}$ of exposure the resistance increased from $90-240 \mu \mathrm{g} \mathrm{ml}^{-1}$ and then to $310 \mu \mathrm{g} \mathrm{ml}^{-1}$. As in the case of 2,2'-methylenebis(4-chlorophenol) the rate of increase was neither linear nor instantaneous. $P$. aeruginosa was inherently much more resistant to thiocarbamate than were the other two cultures. It increased from $250-560 \mu \mathrm{g} \mathrm{ml}^{-1}$.

\section{$\underline{\text { Isothiazolone }}$}

The three bacteria increased in resistance to isothiazolone at similar rates (Figure lc) with the development of resistance to isothiazolone not being random but following a set pattern. The results indicate that the cultures studied would always develop resistance to a similar degree, and at a similar rate.

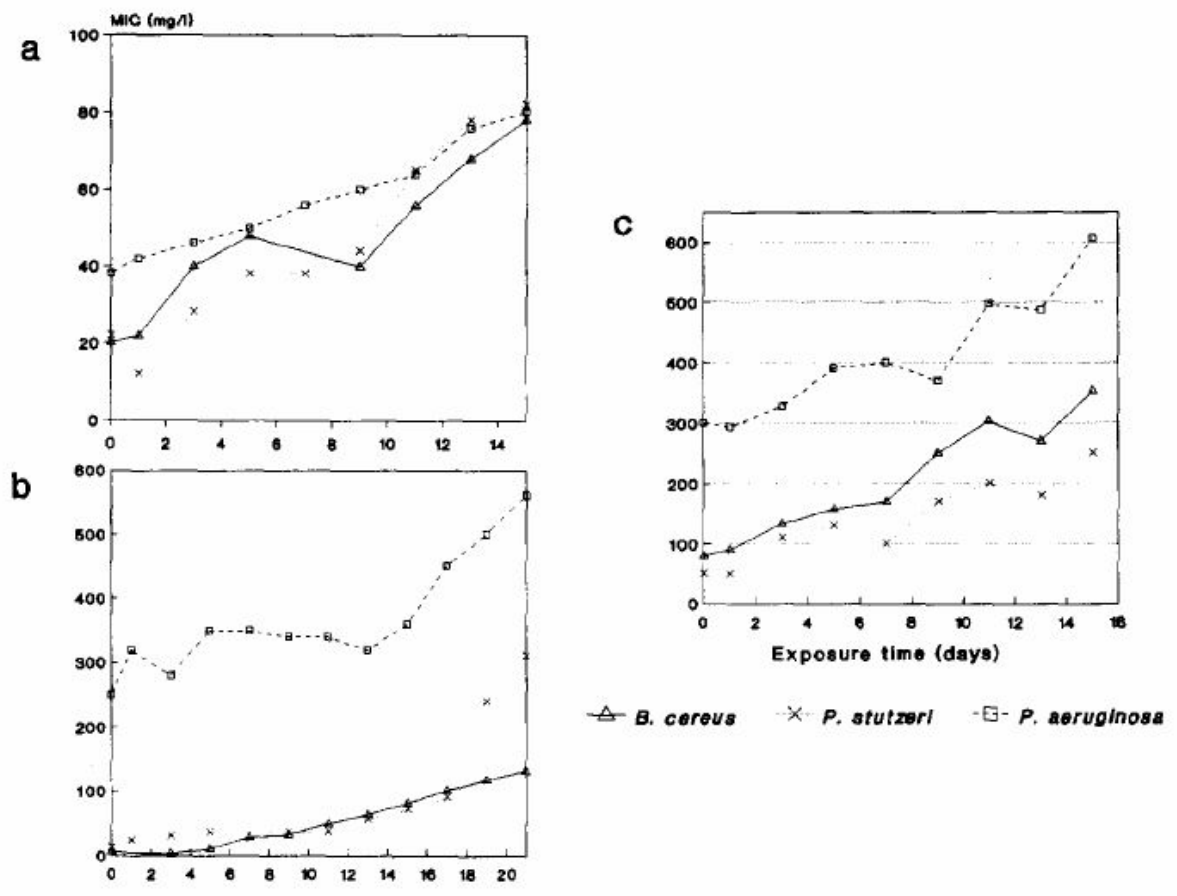

Figure 1. MIC of three water treatment bactericides to three bacteria after growth in R2A broth containing one quarter the previous MIC of bactericide. (a: 2,2'methylenebis(4-chlorophenol); b: sodium dimethyldithiocarbamate; c: isothiazolone (a mixture of $\mathrm{N}$-methyl isothiazolone and 5-chloro- $\mathrm{N}$-methyl isothiazolone).) 
$B$ cereus increased after every exposure from 50 to $300 \mathrm{~g} \mathrm{ml}^{-1}$ after $11 \mathrm{~d}$. It then dropped to $180 \mu \mathrm{g} \mathrm{ml}$ ${ }^{1}$ and increased to $350 \mu \mathrm{g} \mathrm{ml}^{-1}$ after the 15 -day exposure period. The increase in resistance over time was neither linear nor instantaneous. P stutzeri resistance increased fivefold from 50 to $250 \mu \mathrm{g} \mathrm{ml}^{-1}$ over the 15 -day exposure period. The resistance dropped from 123 to $93 \mu \mathrm{g} \mathrm{ml}^{-1}$ after $5 \mathrm{~d}$ and $7 \mathrm{~d}$ respectively. It then increased to 170 and to $200 \mu \mathrm{g} \mathrm{ml}^{-1}$, dropped to 180 and increased to $247 \mu \mathrm{g} \mathrm{ml}^{-1}$ after $15 \mathrm{~d}$. Again the increase in resistance increased over time, but not in a linear fashion. The resistance of $P$ aeruginosa to isothiazolone increased in a non-linear fashion from 300-610 $\mu \mathrm{g} \mathrm{ml}^{-1}$.

\section{$\underline{\mathrm{OAC}}$}

The resistance of $B$ cereus did not increase much in the long run. It did, however, increase during exposure for a few days and then decrease again. This increase - decrease cycle perpetuated during the 69 day period of exposure. The $P$ stutzeri culture also exhibited increase-decrease cycles during the first 59 days of exposure, after which it increased in resistance to $560 \mu . \mathrm{g} \mathrm{ml}^{-1}$. The $P$ aeruginosa culture developed a degree of acquired resistance after sub-inhibitory exposure. After 19 days resistance increased linearly over a 25 day period.

\section{DISCUSSION}

The quantity of bactericide added to water in industrial cooling systems is calculated from minimum lethal concentrations determined under laboratory conditions. Due to the high cost of the volumes of antimicrobial agents required to treat the large volumes of water in industrial cooling systems, addition of bactericide is kept to a minimum. However, the active concentrations of bactericides in systems drop after addition due to a number of factors. Many bactericides react with constituents of the system, eg. proteins, polysaccharides of the biofilm matrix, metal surfaces or with cells, resulting in depletion of the available pool (Characklis, 1990). System blow-down will result in loss of bactericide, and so will adsorption to surfaces. As a result the available concentration of bactericide in the cooling water is lower than required most of the time (Cloete et al., 1992). Therefore, the bacterial communities are exposed to sub-inhibitory concentrations of bactericide.

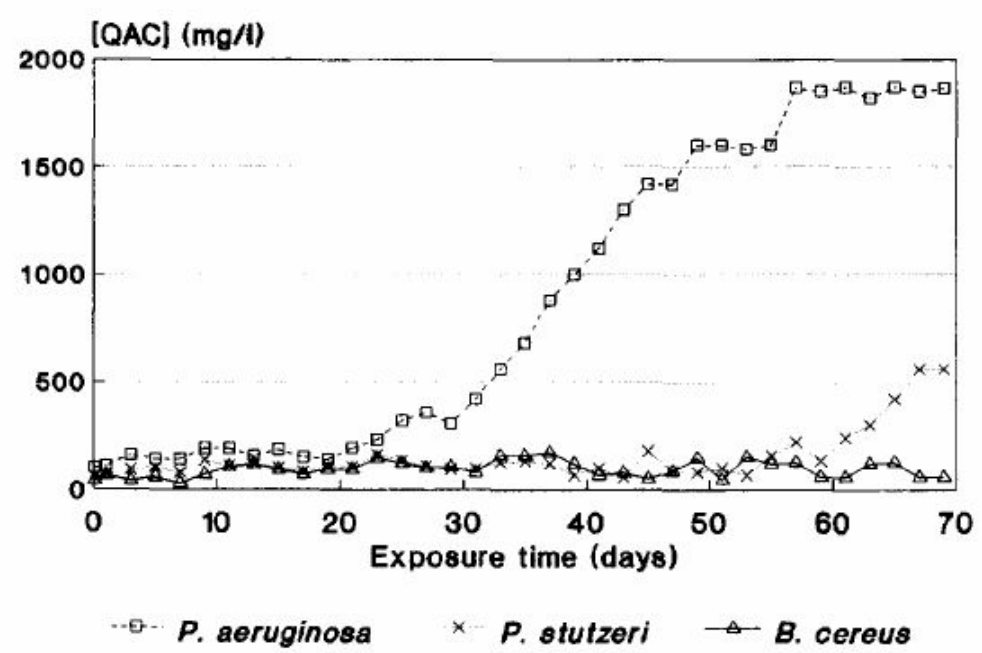

Figure 2. MIC of three bacteria to alkyl dimethyl ammonium chloride after growth in R2A broth containing one quarter the previous MIC of bactericide. 
Bactericide treatment of water systems does not lead to sterilisation, and certain bacteria attain a dominant position over time (Brözel and Cloete, 1992b; Characklis, 1990). Characklis (1990) has ascribed the appearance of such more resistant bacteria to a process of selection. Hereby bacteria which are inherently more resistant to the bactericide, but which are suppressed by others under bactericide-free conditions, would attain the overhand and become dominant in the system. The data presented here demonstrate that certain bacteria are able to adapt to growth in the presence of previously inhibitory concentrations of 2,2'-methylenebis(4-chlorophenol), thiocarbamate and isothiazolone. The phenomenon of bacterial resistance to bactericides in systems can also be ascribed to a process of adaptation and not purely to selection. This would serve to explain why $P$ stutzeri, which is inherently susceptible to 2,2 '-methylenebis(4chlorophenol), was a dominant survivor $36 \mathrm{~h}$ after treatment of a system with 2,2'-methylenebis(4chlorophenol) (Brözel and Cloete, 1992b)

\section{2'-Methvlenehis(4-chlorophenol)}

There was gradual adaption to growth in the presence of inhibitory concentrations of 2,2'methylenebis(4-chlorophenol). Resistance was not acquired directly, as is the case in antibiotic resistance or resistance to formaldehyde where formaldehyde dehydrogenase is constitutively encoded by a conjugable plasmid (Eagon and Barnes, 1986). As the bactericide has to enter through the outer cell membrane to reach its site of action in the cytoplasmic membrane, this adaptation would encompass an alteration in the permeability of the cell envelope to 2,2'methylenebis(4-chlorophenol) (Gilbert and Wright, 1987). The observed pattern of increasing tolerance during continued exposure suggests adaptation to a resistant physiological state as in the case of biguanides (Jones et al, 1989).

\section{$\underline{\text { Sodium dimethvldithiocarbamate }}$}

The resistance of $B$ cereus to sodium dimethyl dithiocarbamate can be ascribed to adaptation, as it follows near straight line or first order kinetics. The initial increase in resistance of $P$ stutzeri also appears to be due to adaptation. However, the increase in resistance of $P$ stutzeri to thiocarbamate after 19 days suggests some form of genomic change. No reports have, however, appeared to date on the mutagenicity of thiocarbamates.

\section{Isothiazolnne}

Again resistance to inhibition increased during the period of exposure, indicating a mechanism of adaptation. The similarity in the kinetics of resistance development to isothiazolone between the 3 replicate cultures shows that the mechanism of adaptation is not random as the 3 cultures would otherwise yield differing data. A mutational change would also be a more random process, and a greater difference between the three data sets would be expected. 5-chloro-N-methyl isothiazolone is, however, an established mutagen (Collier et al., 1990), and its effect on resistant cells will have to be established in more detail.

\section{$\underline{\mathrm{QAC}}$}

The development of resistance to QAC has been previously reported (Jones et al., 1989; Sakagami et al., 1989). However, the resistant strains described were mostly isolated out of systems. Jones et al. (1989) found that an isolate of $P$ aeruginosa cultured in nutrient broth acquired increasing resistance to QAC over time. The increase in resistance was almost linear. Our strain of $P$ aeruginosa did not acquire resistance as rapidly. However resistance did increase to a much greater level $\left(1865 \mu \mathrm{g} \mathrm{ml}^{-1}\right.$ as opposed to $\left.120 \mu \mathrm{g} \mathrm{m}^{-1}\right)$. P stutzeri also acquired an increased level of resistance after extended exposure to the QAC. The mechanism of resistance and the nature of the change are not clear as yet. The increase-decrease cycle in the case of $B$ cereus is an interesting phenomenon which has also been observed during extended exposure to oxidising bactericides such as hypochloric acid (Brözel and Pietersen, 1993). It appears as if the 
adaptive response to the stress cannot be upheld by the culture, and that it is abandoned after a while. This could be an energy-intensive process or a physiological or structural change which affects the cells disadvantageous ${ }^{\wedge}$.

These results show that pure cultures of bacteria dominant in cooling water systems acquire increasing resistance to the non-oxidising bactericides evaluated during growth in the presence of sub-inhibitory concentrations of these bactericides. The decrease in susceptibility of bacterial cooling water communities to non-oxidising bactericides is, therefore, not necessarily due to selection for fitter species, but rather due to the adaptation of certain species to a more resistant physiological state.

\section{ACKNOWLEDGEMENTS}

We thank Edward P. Wallace for technical assistance and Thor chemicals for donating one of the bactericide samples. This research was supported by a grant for research by the Water Research Commission, Republic of South Africa.

\section{REFERENCES}

Brözel, V. S. and Cloeie, T. E. (1991a) Fingerprinting of commercially available water treatment bactericides in South Africa. Water SA 17.57-66.

Brözel, V. S. and Cloete, T. E. (1991b) Resistance of bacteria from cooling waters to bactericides. J. Ind. Microbiol. 8 273-276.

Brözel, V. S. and Cloete, T. E. (1992a) Evaluation of nutrient agars for the enumeration of viable aerobic heterotrophs in cooling water. Water Res. 26 1111-1117.

Brözel, V. S. and Cloete, T. E. (1992b) The effect of bactericide treaunent on planktonic bacterial communities in water cooling systems. Water $S A$ 18, 87-92.

Brözel, V. S. and Pietersen, B. Unpublished data Characklis, W. G. (1990) Microbial biofouling control. In: Biofllms, edited by WG Characklis and KC Marshall. John Wiley \& Sons, Inc., New York. pp. 585-633.

Cloete, T. E., Brözel, V. S. and Von Holy, A. (1992) Practical aspects of biofouling control in industrial water systems. Int. Biodeterior. Biodegr. 29, 299-341.

Collier, P. J., Ramsey, A., Waigh, R. D., Douglas, K. T., Austin, P. and Gilbert, P. (1990) Chemical reactivity of some isothiazolone biocides. J. Appl. Bacteriol. 69, 578-584.

Costerton, J. W. and Lashen, E. S. (1983) The inherent biocide resistance of corrosion-causing biofilm bacteria. Abstracts of the National Association of Corrosion Engineers Conference 246/1 - 246/11.

Eagon, R. G. and Barnes, C. P. (1986) The mechanism of microbial resistance to hexahydro-1,3,5-triehyl-S-triazine. /. Ind. Microbiol. 1, 113-118.

Ford,T. and Mitchell, R.( 1990) The ecology of microbial corrosion. Adv. Microb. Ecol. 11231-262.

Franklin, T. J. and Snow, G. A. (1981) Biochemistry of Antimicrobial Action. (3rd edn.) Chapman and Hall, London.

Gilbert, P. and Brown, M. R. W. (1978) Influence of growth rate and nutrient limitation on the gross cellular composition of Pseudomonas aeruginosa and its resistance to 3- and 4-cblorophenol. J. Bacteriol. 133,1066-1072.

Gilbert, P. and Wright, N. (1987) Non-plasmidic resistance towards preservatives of pharmaceutical products. In: "Preservatives in the Food, Pharmaceutical and Environmentla Industries" edited by Board, R. G., Allwood, M. C. and Banks, J. G., Blackwell Scientific Publications, Oxford, pp. 255-279.

Heinzel, M. (1989) The phenomena of resistance to disinfectants and preservatives. In: "Industrial Biocides" edited by Payne, KR, John Wiley and Sons, Chichester.pp. 52-67.

Jones, M. V., Herd, T. M. and Christie, H. J. (1989) Resistance of Pseudomonas aeruginosa to amphoteric and quaternary ammonium biocides. Microbios 58,49-61.

LeChevalier, M. W., Cawthorn, C. D. and Lee, R. G. (1988). Inactivation of biofilm bacteria. Appl Environ Microbiol. 54, 24922499.

Sakagami, Y., Yokohama, H., Nishimura, H., Ose, Y. and Tashima, T. (1989) Mechanism of resistance to benzalkonium chloride by Pseudomonas aeruginosa. Appl. Environ. Microbiol. 55, 2036-2040.

Wallhaüßer, K. H. (1988) Praxis der Sterilisation: Desinfection - Konservierung Keimidentifizierung - Beitreibshygiene. Verlag, Stuttgart. 